\title{
The Professional Development of Employees in Banks of Pakistan: A comparative study of public and private banks in Punjab Pakistan
}

\author{
Muhammed Nawaz \\ MS Scholar, Department of Management Sciences \\ The Islamia University of Bahawalpur, Pakistan \\ Tel: +92- 306-4907541 E-mail: muhammednawazmalik@gmail.com \\ Muhammad Irfan Shakoor \\ MS Scholar, Department of Management Sciences \\ The Islamia Unirversity of Bahawalpur, Pakistan \\ Tel: +92-315-7358586 E-mail: Irfan44471@ yahoo.com \\ Syed Shahzaib Pirzada (Corresponding author) \\ MS Scholar, Department of Management Sciences \\ The Islamia University of Bahawalpur, Pakistan \\ Tel: +92-321-6800804Ｅ-mail: Shahzaib86pirzada@gmail.com \\ Doi:10.5296/ijld.v3i5.4520ＵRL: http://dx.doi.org/10.5296/ijld.v3i5.4520
}

\begin{abstract}
:
The primary objective of the research was to determine the influence of Professional development of employee's knowledge, skills and experience by the Training. A phenomenon widely quoted in HR literature as professional development. To this end, the researcher initially identified twenty elements constituting professional developments of employees of banks in Punjab Pakistan. Subsequently, the magnitude of influence of each constituent elements of professional development in different functional areas of banking operations was analyzed.

Co-deductive method of research was followed. The instrument of data collection was a questionnaire comprising many items which measured perception of respondents about the level of different variables ( improvement of quality of research, orientation of new employees, solution of organization problems, preparation of staff for promotion, provision of personal growth of employees, sufficient time of training, adequate schedules of training, effective contents of training, highly competent trainers and adequate provision of training material) available to them in the training environment. Besides, the questionnaire measured perception about degree of Training in most important areas of banking operations. Sample size of this research consisted of 100 bank officers of 7 banks with 20 branches located in Bahawalpur. Data was collected by personal contacts. All twenty variables showed significant t- results. Additionally the strength of relationship was measured by the help of Mean and standard deviation at 0.05 significance level. The study brought out a number of important findings which necessitated formulation of HR initiatives for bringing about tangible improvement in professional developments at banks that will eventually enhance levels of training.
\end{abstract}

Key Words: Professional development, Trainings of the employees, Transfer of training in workplace 


\section{Introduction}

Professional development is the process of developing employee's, skills and experience so that the objective of the employment can be achieved. A company can obtain its tasks by developing employee's profession according to their field. Professional development is not only beneficial for the organization but it is also important for the employees. Professional development is based upon three functions. First one is the development of knowledge of the employees, second one is the development of the skills of the employees and the third function is the development of the employee's experience. If we take knowledge, how the development of the knowledge of the employees is possible. This is the main issue for the employees of the organization. When an employee is selected the employer thinks that employee is complete by anyway because he has gotten the required education by the employer. That thinking of the employer is not as accurate as he thinks because after getting the degree many other improvements remain incomplete which necessarily enhance the knowledge of employee and without these extra improvements he is not able to face many flourishing problems due to the advancement in technology and rapid increase of globalization. The improvement in the knowledge of employees is necessary to do work productively and efficiently. The fact is that the continuous about his field is successful for any individual employee and for the benefit of whole organization. If we take the second function for the development of employees is experience. An experienced person can solve the problem arising in front of him while working in the organization. Employees who after getting education directly to the industry can't perform well as according to the requirement of the employer. Inexperienced person can't handle the work therefore he can't satisfy the organization's required goals. As experience increases employee is going to be able to make decision as efficiently and in very short time. We take the third function which has to be developed by the employer for the improvement of employees is the skills of the employees. A non skilled person is in difficulty when he leaves a low level organization and goes to the new high level organization he is not able to perform well because of advance technology. You can take the example of software different packages if a person is not able to work out on new software now employer has needed to develop his skills relevant to his field. The concept of Islamic banking took place in 1979 to eliminate Reba (interest) by promotion of risk sharing practices for economic prosperity in the country. Again in 1990 structural reforms took place when all the private banks were nationalized in 1978 were deregulated as privatized due to which the banking industry growth started slowly and slowly in the start. In 2001 a detailed criteria was issued for the establishment of full fledged Islamic banking in private sector. SBP also started the provision of microfinance bank in the country, which were the best means to poverty alleviation. As Pakistan is the most important country of the Asia region, having mixed economy country. Many sectors survive in it but the services sector of the Pakistan has the major part of contribution in the GDP of the country. After the late reforms of 1990, the banking sector of the Pakistan become so strong that even in 2008 the financial crises in the Europe disturbed almost, many largest financial institutions of America were go insolvent but these crises can't harm the financial sector of Pakistan. But as we see in Pakistan from benefit sides and make comparison of Pakistan banks with the foreign banks, in foreign banks many employee development programs are launched by those banks which are not being seen in the banks of Pakistan. No such training programs are launched for the employees working for many periods of time in these banks. SBP sometimes try to launch these programs with the help of IMF and WB but these programs cannot give result positive because of govt. Intervention and religious problems in the country. In these programs many changes were brought not only for the development of the 
employees as for the development of the financial institutions working in Pakistan. How our study is different as compared to the different literature we studied? Definitely study of our research is something different as according to the literature we studied which we have found from different sources. The literature we studied is different because all the literature point out or justify the issues and practices which arise in banking sector of Pakistan from different point of view, they covered many topics other than development of professionals working in the banks of Pakistan. But our research is almost for the professional development of professionals working in Pakistani banks. But literature we studied pointed out the issues like that motivation, role ambiguity, working environment, role conflict, lack of feedback, rapid technological changes, promotional rewards, work overload and stress etc. Which are not directly relate to our required topic but support our topic indirectly. Our study contains the professional development of bankers, some of three functions knowledge, skills and experience. Gaps between our research and the literature we studied. Basically our research is concerned with the issues of the professional development of the employees working in the banks of Pakistan. These issues are almost of lack of training of the employees for the enhancement of the knowledge, skills and experience of the employees working in the banks of Pakistan. The issue of professional development of employees arises due to the rapid changes in the global business environment especially in the banking sector of the Pakistan. The need of this professional development took place when one bank opened its branches in foreign countries and some of its employees shift to those countries they were not aware of the environment, knowledge, experience and skills which were need to fulfill the requirements of the customers of that country. The research papers and articles which we studied do not clear these gaps which our research wants to study. What are the benefits of our study to banking industry? Obviously our research will be of great importance to the banking industry of Pakistan while planning for the professional development of the employees working in the banks. Without the development of professionals when a specific problem arises in a bank to which your bank can not solve have to hire a consultant and pay higher fees for the solution of that problem due to which the cost of the bank services increases as compared to your competitors then you cannot compete the market and at last you have to close your business. Due to the development of the professions of the employees working in banks will enhance their knowledge, experience and skills to fulfill the emerging needs of the customers both your own country and of foreign country and what their employer also expects from them. Many problems will be solved by the banks by using the findings of research paper like training of employees, participating in the international conferences by the employees and getting within the organization trainings and skills development programs will be benefitted for the employees to work efficiently, effectively and in time. And now they are able to make decisions regarding the problems faced by them. When we will take all such steps for the development of the employees, our employee's performance will stimulate as according to the development.

Our study has many objectives but major are being discussed below:

$>$ To provide the banking industry suggestion for meeting the current trends of the market.

$>$ To provide the customers a satisfactory banking services as they expect from any other advance bank.

$>$ Maximum and efficient use of resources available by banks so that they can achieve the goals which they have developed for their own growth and for the customer's requirements. 
To satisfy/fulfill the desires of employees as according to their knowledge, experience and skills.

\section{Literature Review}

Basically the development of human resource is always run by the knowledge based decision and actions. Today organizations are facing the lack of skilled human capital which is a great hurdle for the organizations. Therefore the organizations can solve this issue /challenge by providing professionally structured training programs to fulfill the organizations strategic goals. Therefore the training and development of the employees is much important for both the individuals and the organizations. Now it is said by the think tanks that the investment in training and development plays a pivotal role for the improvement and growth of the employees ( Roailler \& Gold stain,1993). Professional development is process of knowledge, skills and attitudes by learning from the trainings whether these are on the job training and even this learning will be the maintenance of the professionals for a long period of time in future (Bald win \&ford,1988). Newstrom (1986) asserts that positive training is indented by obtaining knowledge and skills in the off- the job period. This learning will apply on the job and to enhance the skills over a period of time. Different researchers present their views, they argued that the needs of training and development and their objective should be defined in terms of dynamic in behaviors and enhanced effectiveness on the side of organization, where groups and teams work instead of enhancement of in knowledge, skills and abilities (Bremley and Kitson, 1994). Many researchers argued training as investment for the growth of performance in the organization but some argued that training aim is to improve the attitudes, skills and knowledge of the employees on the job. But the basic purpose which is seen in the organization is training of the employees that are conducted for creating a fit between the job requirement and the person. Training plays a pivotal role for the improvement in the performance of the employees working in the organizations. Training programs are arranged for the realization of required change in the behavior of the employees which are reflected in attitude, knowledge and skills (Blumenfeld and holland, 1971). Roiled and Goldstein(1993) insist that training is managed process of acquiring skills, knowledge, attitudes, concepts and rules in one developed environment which brings improvement in the performance of another environment. Another view from researcher who argues that training is considered a systematic struggle by the organization to attract employees learning job related competencies (Neo, 2002). Greenhaus, Callanan and Godshalk (2000) assert that we see the training in traditional view we conclude that training activities were conducted for delivering instructions to the employees relevant to their required job tasks and give orientation to the new comers. These newcomers were given the orientation about the organizational goals, policies, procedures and practices. Moreover training has also been collaborated with socializing the new trainees in their tasks best interaction and pattern and rules required to perform the specific tasks (Daft and Stees, 1986). Those organizations which have their own training departments normally play the act of differentiating specific technical and managerial skills which are necessary for performing the advance job tasks. Greenhaus, callanan and Goldshalk (2000) express training in term of three different approaches. First is training while working which means apprenticeship with the employees of the organization within their same department. Second is working while training it means a way of formal training by rotating the jobs of newcomers in different departments and projects of the organization. Third one is full time training which is involved to look after the rotations of their employees through different departments and in special projects. But as well as 
effective training is concerned that the employees should ready for establishing a learning environment. In second step the assurance of application of training of knowledge and skills in the job environment is important (Neo, 2000). Draft and Steers (1986) assert that in all the above mentioned perspectives training and development includes flexibility in thinking and assessment of training department in the organizations. To develop training teams is to start and to improve the change in employees previous knowledge and skills. It is realized by the researchers that a study on training will not be taken complete unless and until the achievements of training are implemented in the workplace. In past era, to prepare employees for that future tasks and their training for that purpose was not given any importance (Neo, 2002). But in the present era due to substantial growth in the scope of business market for employment has become much complicated and diverse. Now global organizations are going to provide the trainings of cultural growth for enhancing their productivity to the employees working outside the domestic country. Those organizations are considered competitive which have trained and adequate workforce. It is thought that training in single is not the solution of every problem containing poor performance low productivity. Organizations spend a substantial part of investment on training to attract the employees for obtaining competencies, which are relevant to their job requirements (Neo et al., 2006). It is needed an immense level research for the transfer of knowledge and skills in the workplace environment, because the existing literature concentrate on overall change of training, contents of training course, quality of instructions given to employees and the training environment provided to the employees. It is thought that the symbol transfers work as a bridge between classroom and actual performance of the employees (Swinney, 1989). The estimate of the expenders which an organization spends on the professional development is very disappointing.

\subsection{Model of Transfer Process by Baldwin and Fords;}

This model consists of three main heads (1) Training input (2) training output (3) condition of transfer. Training inputs consists of trainee qualities, training design and working environment. In each above three inputs first qualities of trainee which includes three components like that ability of worker, personality of the worker and motivation level of the worker or employees. In second input design, Training design which is included principle of learning should be provided by the trainer to the trainee, sequence of learning, which means a structured framework of leaning should be provided to the trainee, last means which things will be teach to the trainee during training. Now third and last training input is work environment which has further two components, one is support which means such environment should be provided to the trainee which he can easily perceive. Second is opportunity to use, it means he should have been the availability of environment if he leaves the organizations. Means training meet each aspect both internal and external to the organization. Second head of model is training output which is consists of one component which means when all the inputs of training provided, then the output will be the trainee will have been able to work in the environment. Third head of the model is condition of transfer which means generalize the training into work environment. Optimize HRM practices put a great part in the increment of productivity of the organization (Bloom and Veen Reenen, 2007). HRM training may have positive or negative effect on the turnover and productivity of the financial institutions (Sels et al., 2006). Petrescue and Simmons, 2008) explained that HRM training and development increase the level of satisfaction, their motivation level and their overall satisfaction on the actual job performances. Davis and Newstorm (1999) argued that job satisfaction can be obtained by providing the employees special training and best rewards and incentives on their performances. Guest (2004) and Silla et al. (2005) asserted that the promotion of an employee depends on almost 
on the training programs because if some has obtained training about the job tasks up to his current job then his selection for the upper designation will be easy. He will not have to face any difficulty because your top management will be fully aware of your performance and training. Flexible changes are only possible if there is a complete understanding of tasks by the management. Tanke (1990) asserted that due to the lack of professionals development many issues arise like behavior of supervisors with their employees, dissatisfaction of employees because of lack of coordination of top and lower level management. These are the things which compell the employees to leave the organization. Personal traits, leadership attitudes and job autonomy can be achieved only by obtaining the training in the organization in which they are performing their actual tasks because they will implement it easily in their workplace environment (Nguyen et al., 2003). Eason (1989) explained that low investment in training and development lack of top management support. Workers unions and rude behavior of supervisors are the main hurdles for generating the empowered teams. Due to lack of training and development of professionals the mistakes of planning occurs which derail the organization overall performance from its regular track (Emery, 1992). In developing countries the organizations considered training very factor that enhances the value of performances of the organization. In Pakistan all the financial sector (banking sector) is under the custody of SBP that supervises the corporate governance of banks and their reforms and policies and make regulatory frameworks for them. When SBP makes policies and setting out the responsibilities of the respective board of directors of banks, it needs direction to concentrate on policies making and supervision and many other things in the establishment of banking business. Directors are hoped to set up board committees in very alarming areas and make the training programs possible (Akhter, 2008). SBP took many serious steps for bring changes in management in November 2002. With the purpose to create and acceptance and ownership of new vision of SBP Strategies and multi values for the appraisal of performance on the basis of mission statement of SBP. It was also taken into consideration that the development of professionals and technology improvement were the important factor of change in SBP. Therefore other commercial banks also concentrate on those two factors to meet the future requirements. To bring improvement in these two factors of PEST (political, economic, social, technological) analysis were carried out. This analysis was conducted to assess the external environment influencing the SBP and what are the issues that are needed to change. The analysis of SWOT (strength, weaknesses, opportunities, threats) was also carried out to evaluate internal environment of SBP and what obstacles are needed to change. SWOT was carried out in form of human resource informal, technological and physical etc. The main object was to analyze the human capital development, what are related issues concerning HR management, training and development and structure of the organization work culture of the organization, what managerial styles are used in the organization. If we take SWOT in term of physical, it means factors related to building structure, dead stock and defining the working environment. Information resources involve what statistical (data, figures) is required for the supporting activities. Technological resources are included managerial, physical and information technology. It covers all the technology to fulfill the requirement of above strength and weaknesses of the resources were taken into consideration while improving or enhancing performance and training and development process (SBP, 2005). SBP (2007) reviewed that different financial reforms and processes of privatization of banks led to drastic increase in the competition. Banks operations were become much complex with the innovation in financial instruments and flourishing globalization. Now it become necessary for the banks to come out in the external environment with the list of new products and services and developed professionals to meet the intense national and international competition. As those economies which mostly depend 
on trade, commerce and the allied financial activities which is generally driven by the banking laws. These banking employees need special skills and experience to handle the complicated operations and to fulfill the issues of fastly changing environment of banking sectors. The SBP financial sector assessment report 2004 describes dynamic growth in banks products during the last 20 to 30 years is due to drastic change in the financial sector by globalization. Due to globalization increased the consumer banking launch new products like that car financing, house building finance and ATM. Therefore local and regional banks started to operate in new area of lending in these SMEs banks, Islamic banking, ZTBL, Commercial banks are included. Many large banks working in Pakistan have established their training centers for their employees to meet the new challenges arising due to technology advancement, changing market environment and rapid increase in globalization. National Institute of Banking and Finance (NIBF) provides training to the employees of banks in Pakistan. According to SBP annual performance review 2007 intends that incomes received by the NIBF from the banks working in Pakistan has increased up to $50 \%$ from 2006-2007. The purpose of showing these figures means that banks are providing a lot of training to their employees to facing the globalized challenges. Similarly institute of bankers Pakistan has taken many initiatives for the development of professionals working in banks. The management development centers of banks in Pakistan have structured many trainings programs for enhancing professional banking training to new employees and middle level managers. At both level of training many core banking operations have been included which are credit and risk management, marketing of financial services, soft skills and management related training aspects online banking. Training Programs in Banks of Punjab are almost included functional courses and managerial courses. Functional courses are important for enhancing professionalism while the managerial courses are conducted for the flourishing of banking officers. SBP structures guidelines for the implementation in training and development programs conducted by the banks for their employees. All these guidelines are structured based on identifying developed objectives which a training program has to cover up included from the requirement of an individual to the person having the institution. It means all the employees without mentioning designation and the grade of the employees. SBP annual report 2005 recommended that training should be divided into four main areas, foundation, intermediate, advanced and managerial level. Compulsory courses are started for the new comer employees are conducted while intermediate level courses are started for the promotion of employees. Advanced level courses are conducted for the senior or managerial positions while managerial level courses are started for managers to develop the needs of organization. The purpose of managerial level courses is to produce future leaders with the magnitude sense of banking industry aims and vision. In this current era of competition it is a much pressure for the management of corporations to reduce the prices of their products and the quality of services to be improved in financial sectors of Pakistan especially in baking sector. To prove the quality of the product and services the bankers required an efficient management. The profitability of any organization depends on the potential of the employees of that organization. Many organizations are using technological instruments for the development of employees. Advancement in technology not only brought challenge but also the solutions for these challenges. Many methods are used for the development and training of the employees in the work place. Each and every learner is provided a solution that how he can learn. Problem of distance has been reduced by the enhancement in technology.

\section{Methodology}

The purpose of this research was to analyze constituents of professional development of bankers, find out level of their availability and extent of influence exerted by them on actual work task. This 
problem was approached in two ways, firstly by adopting the descriptive statistical approach which explained only mean tendencies of the variables like professional development of employees and other individual elements of training environment. The second approach related professional development of bankers to training environment more rigorously. First we probed which elements of training environment effects professional development of bankers, then by using t-test we tested the significance of each parameter. Such an approach enabled us to assess relevance of variables in explaining professional development. It was quite possible that relative importance of some variables might be stronger and positive while others might be relatively weaker in influencing transfer of training. 


\section{Macrothink}

International Journal of Learning \& Development

ISSN 2164-4063

2013, Vol. 3, No. 5

4. Findings and discussion

Table 1. Empirical results of the study

\begin{tabular}{|c|c|c|c|c|c|c|c|c|c|c|c|c|c|c|c|c|c|c|c|c|c|c|c|}
\hline \multicolumn{3}{|c|}{ Designation } & \multicolumn{3}{|c|}{ Experience } & \multicolumn{3}{|c|}{ Types of bank } & \multicolumn{3}{|c|}{ Orientation } & \multicolumn{2}{|c|}{ Mentoring } & \multicolumn{2}{|c|}{ Couching } & \multicolumn{2}{|c|}{ Seminars } & \multicolumn{2}{|c|}{ Conference } & \multicolumn{2}{|c|}{$\begin{array}{l}\text { Work } \\
\text { shops }\end{array}$} & \multicolumn{2}{|c|}{ Assessment } \\
\hline Details & 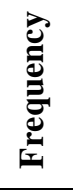 & 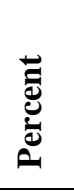 & 氠 & 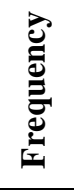 & 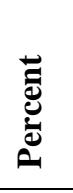 & 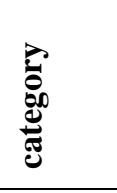 & 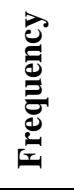 & 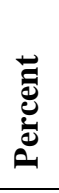 & $\begin{array}{l}\overline{\bar{\pi}} \\
\text { 苞 }\end{array}$ & 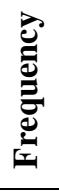 & 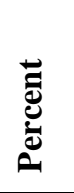 & 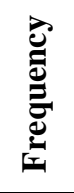 & 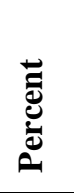 & 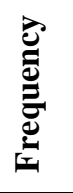 & 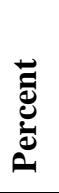 & 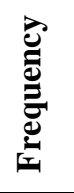 & 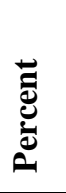 & 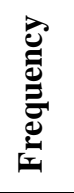 & 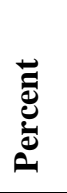 & 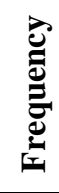 & 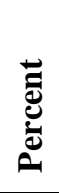 & 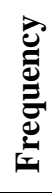 & 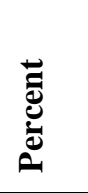 \\
\hline Officer & 42 & 42 & $1-10$ & 73 & 73 & Public & 50 & 50 & Filled & 42 & 42 & 37 & 37 & 55 & 55 & 51 & 51 & 55 & 55 & 36 & 36 & 51 & 51 \\
\hline Manager & 39 & 39 & $11-20$ & 14 & 14 & private & 50 & 50 & Empty & 58 & 58 & 63 & 63 & 45 & 45 & 49 & 49 & 45 & 45 & 61 & 61 & 48 & 48 \\
\hline Cashier & 9 & 09 & $21-30$ & 5 & 05 & & & & & & & & & & & & & & & & & & \\
\hline Customer & 10 & 10 & $31-40$ & 7 & 07 & & & & & & & & & & & & & & & & & & \\
\hline & & & $41-50$ & 1 & 01 & & & & & & & & & & & & & & & & & & \\
\hline Total & 100 & 100 & & 100 & 100 & & 100 & 100 & & 100 & 100 & 100 & 100 & 100 & 100 & 100 & 100 & 100 & 100 & 97 & 97 & 99 & 99 \\
\hline
\end{tabular}




\subsection{Description for the above table}

The respondents of the both institutions either public or private banks who gave us response are at designation given in table no.1 below. 42 officers, 39 managers, 9 cashiers and 10 customers took part in filling the questionnaire. The experience of the respondents were that 73 respondents are having the experience falls between one to ten years 14 respondents having the experience of eleven to twenty years and the 5 respondents having the experience of twenty one to thirty years. Seven respondents are the experience of thirty to forty years and one respondent is having the experience of forty to fifty year. Total hundred respondents gave the response fifty respondents were from private banks and fifty respondents were from public banks. Orientation as the way of training the employees the 42 respondents say that orientation is necessary others are not agree. Only 37 respondents are agreed with the training of mentoring while the other 63 respondents are disagreeing with this type of training. Only 55 respondents are agreeing that coaching is suitable method for the development of employees while other 45 respondents are not agree with this method. 51 respondents are agree with method of training that is provided in their institution while other are not agree and say that in their organization is not using this method of training. 55 respondents say that their organization is providing the training like conference while other 45 respondents say that their organization is not providing such type of training to the employees. 51 respondents say that their organization is using workshop for the training of the employees while 48 respondents say that their organization is not providing such type of training to the employees while others one respondent give no response. 36 respondents say that their organization is using assessment for the training purpose of the employees while 61 respondents are of view that their organization is not using such method for the employee's development. The other 3 respondents did not give any response.

Table 2. Improvement of Quality and Research

\begin{tabular}{|c|c|c|c|c|c|c|}
\hline \multirow{3}{*}{$\begin{array}{l}\text { Perceived Issues and } \\
\text { challenges faced by } \\
\text { private and public bank } \\
\text { of Punjab Pakistan }\end{array}$} & \multicolumn{4}{|c|}{ Types of institutes } & \multirow[t]{2}{*}{$t$} & \multirow[t]{2}{*}{ Sig. (2 tailed) } \\
\hline & \multicolumn{2}{|c|}{ Public Banks } & \multicolumn{2}{|c|}{ Private Banks } & & \\
\hline & Mean & $\begin{array}{l}\text { Std. } \\
\text { Deviation }\end{array}$ & Mean & $\begin{array}{l}\text { Std. } \\
\text { Deviation }\end{array}$ & & \\
\hline $\begin{array}{l}\text { Improvement of Quality } \\
\text { and Research }\end{array}$ & 3.82 & .850 & 3.84 & .842 & -.118 & .906 \\
\hline
\end{tabular}

Statistics: as result indicated that the mean score for the public banks is 3.82 and for the private banks is 3.84 with the standard deviations of .850 and .842 respectively. The $t$ score for the equality of means is -.118 with $\mathrm{p}$ value .906 . It means that there is no significant difference between two means.

Public reasoning: as you see that the mean score of public banks is higher than the private banks it means that public banks employees are more satisfied than the private banks employees that the purpose of our bank to develop the employees for improve the quality of services and to enhance the research skills of the employees.

Private reasoning: as you see that the mean score of the private banks is less than the public banks mean score but these are also agree that the purpose of professional development in private banks is to update the services quality and research skills of the employees.

Comparison analysis: From the above results it is concluded that there is a minor difference between public and private respondent's opinions. Both are agreeing that these developments 
are helpful for the improvement of quality of services and to increase the research skills of employees so that they can develop new ideas regarding the banks goals and objectives. As mean and standard deviation are positive which intend that respondents are satisfied? Respondents are of the view that training and other programs conducted in their bank are useful for the enhancement of their existing knowledge and experience.

Table 3. Orientation of New Employees

\begin{tabular}{|l|l|l|l|l|l|l|}
\hline $\begin{array}{l}\text { Perceived Issues and } \\
\text { challenges faced by } \\
\text { private and public bank } \\
\text { of Punjab Pakistan }\end{array}$ & \multicolumn{2}{|l|}{ Types of institutes } & $t$ & Sig. (2 tailed) \\
\hline & Mean & $\begin{array}{l}\text { Std. } \\
\text { Deviation }\end{array}$ & Mean & $\begin{array}{l}\text { Std. } \\
\text { Deviation }\end{array}$ & & \\
\hline & 3.53 & 1.063 & 3.65 & .948 & -.602 & .549 \\
\hline $\begin{array}{l}\text { Orientation of New } \\
\text { Employees }\end{array}$ & & Public Banks & Private Banks & & \\
\hline
\end{tabular}

Statistics: As result shows that the mean of public banks is 3.53 and of the private banks are 3.65. The standard deviation of public and private banks is 1.063 and .948 respectively. The $t$ value is -.602 with the $\mathrm{p}$ - value of .549 and with the significance level of .05 which show that there is no significance difference between the opinions of public and private banks respondents.

Public reasoning:_ As it is shown in the table above that the mean of public banks are 3.53 which is lesser than the mean of private banks. It tends that the respondents of public banks are less satisfied as compared to the private banks because they are of the view that the major purpose of their bank is not to orient their employees. But up to some extent they are satisfied that the public bank orient their employees.

Private reasoning: As from the table above that the mean of private banks is 3.65 which is higher than the mean of public banks. It is concluded that the respondents of private banks agree that the purpose of their bank is to orient new employees about their organization and the job task. They are satisfied because they are of the opinion that without the orientation of new employees it is impossible they will perform tasks very well.

Comparison analysis:_From the above two reasoning it is concluded that both public and private banks respondents are agreed at one point the purpose of banks is to orient new employees. The public banks respondents are not as much agrees as private banks respondents. Public banks respondents are of the opinion that their bank main purpose of professional development is not to orient new employees while on the other hand private banks respondents are agree that the main and first priority of their bank about professional development is to orient new employees. They are of the opinion that without orienting new employees it is impossible for the new employees to work efficiently and effectively while the public banks respondents are less satisfied with this statement.

Table 4. Solution of Organization Problems 


\begin{tabular}{|c|c|c|c|c|c|c|}
\hline \multirow{3}{*}{$\begin{array}{l}\text { Perceived Issues and } \\
\text { challenges faced by } \\
\text { private and public bank } \\
\text { of Punjab Pakistan }\end{array}$} & \multicolumn{4}{|c|}{ Types of institutes } & \multirow[t]{3}{*}{$t$} & \multirow[t]{3}{*}{ Sig. (2 tailed) } \\
\hline & \multicolumn{2}{|c|}{ Public Banks } & \multicolumn{2}{|c|}{ Private Banks } & & \\
\hline & Mean & $\begin{array}{l}\text { Std. } \\
\text { Deviation }\end{array}$ & Mean & $\begin{array}{l}\text { Std. } \\
\text { Deviation }\end{array}$ & & \\
\hline $\begin{array}{l}\text { solution of organization } \\
\text { problems }\end{array}$ & 3.37 & .906 & 3.55 & .914 & -.999 & .320 \\
\hline
\end{tabular}

Statistics: The mean of public banks is 3.37 and the private banks is 3.55 while the standard deviation of public and private banks is .906 and .914 respectively. The t value is -.999 and $p$ value is .320 , the $\mathrm{p}$ value shows that there is significance difference between two means.

Public reasoning:_The mean of public banks is 3.37 and the mean of private banks is 3.55 which show that the mean of public banks is less than the mean of private banks. The respondents of the public banks are of the view that the purpose of their bank is not to conduct the professional development programs for the solution of organization. They are also of the opinion that their bank don't want to provide trainings through which employees can solve the problems of the organization.

Private reasoning: The mean of the private banks is 3.55 and the mean of public banks is 3.37 which intend that the mean of the private banks is higher than the public banks mean. The respondents of the private banks are of the view that the main purpose of their bank is to solve the problems of the organization while providing the employees training and other professional development programs.

Comparison analysis: from the above two reasoning it is being make comparison which results that public banks respondents are not satisfied with the statement that the purpose of their bank is to develop the employees for the solution of the organization problems. But on the other hand the respondents of the private bank are agree with the statement that their bank main purpose of is provide the trainings programs to the employees so that the problems of the organization can be eliminated. If these trainings are not provided to the employees the survival the organization comes to an end.

Table 5. Preparation of Staff for Promotion

\begin{tabular}{|c|c|c|c|c|c|c|}
\hline \multirow{3}{*}{$\begin{array}{l}\text { Perceived Issues and } \\
\text { challenges faced by } \\
\text { private and public bank } \\
\text { of Punjab Pakistan }\end{array}$} & \multicolumn{4}{|c|}{ Types of institutes } & \multirow[t]{3}{*}{$t$} & \multirow[t]{3}{*}{ Sig. (2 tailed) } \\
\hline & Public & Banks & Privat & Banks & & \\
\hline & Mean & $\begin{array}{l}\text { Std. } \\
\text { Deviation }\end{array}$ & Mean & $\begin{array}{l}\text { Std. } \\
\text { Deviation }\end{array}$ & & \\
\hline $\begin{array}{l}\text { Preparation of Staff for } \\
\text { Promotion }\end{array}$ & 3.24 & 1.071 & 3.51 & 1.023 & -1.254 & .213 \\
\hline
\end{tabular}

Statistics: the mean of the public bank is 3.24 and the mean of the private bank is 3.51 while the standard deviation of the public bank is 1.071 and the standard deviation of private is 1.023 . The $t$ value of these two means is -1.254 with the $p$ value of the .213 which shows that there is significant different among these means at the .05 level of confidence.

Public reasoning: The mean of the public banks is 3.24 which is lower than the mean of the private bank it means that the respondents of the banks are not so satisfied with the above statement that the purpose of their bank about professional development is not to prepare the 
employees of the bank for their promotion. They are of the view that their bank policy is not to promote the employees on the basis of the provision of the trainings provided to the employees. Private reasoning: the mean of the private bank is 3.51 which are higher than the mean of the public bank it means that the respondents of the private bank are satisfied with the statement the purpose of their bank is to provide employees so that they can be trained and experienced employees can be promoted for achieving the organization goals.

Comparison analysis: from the above two reasons it's concluded that the respondents of the private banks are agree with the statement that the purpose of their bank is to provide trainings to their employees for promoting them for future achievements. While on the other hand the respondents of the public banks are of the opinion that the purpose of their trainings and the development programs is not to promote employees but to increase the efficiency of the employees for their current job tasks.

Table 6. Provision of Personal Growth of Employees

\begin{tabular}{|l|l|l|l|l|l|l|}
\hline $\begin{array}{l}\text { Perceived Issues and } \\
\text { challenges faced by } \\
\text { private and public bank } \\
\text { of Punjab Pakistan }\end{array}$ & \multicolumn{2}{|l|}{ Types of institutes } & $t$ & Sig. (2 tailed) \\
\hline & Public Banks & Private Banks & & \\
\hline $\begin{array}{l}\text { Provision of Personal } \\
\text { Growth of Employees }\end{array}$ & 3.56 & $\begin{array}{l}\text { Std. } \\
\text { Deviation }\end{array}$ & Mean & $\begin{array}{l}\text { Std. } \\
\text { Deviation }\end{array}$ & & \\
\hline
\end{tabular}

Statistics: the mean of the public banks is 3.56 and the private banks is 3.81 with the standard deviation of the public and private banks is .918 and .798 respectively. The t value of the two means is -1.412 with the p-value of .161 which shows that there is significant difference between the two means.

Public reasoning:_the respondents of the public banks are somehow agreeing that the provision of the trainings to the employees have a positive impact on the performance of the employees. They are also agreeing with this statement that their bank purpose is to provide the trainings to their employees so that the employee's personal growth can be enhanced so that they can work efficiently. Some of the interviewees elaborate that the purpose of the training is as not hundred percent to enhance the personal growth of the employees.

Private reasoning: the respondents of the private banks are also agree with this statement more strongly as compared to the public banks that the main purpose of their bank is to enhance the personal growth of the employees. They are of the opinion that when a person individual growth takes place he works as well. Therefore they are of the view that without the provisions of adequate training for the personal growth of the employees it is difficult for an organization to grow rapidly.

Comparison analysis: the respondents of both public and private banks are agree with this statement that their banks step toward the enhancement of the personal growth of the employees positively effect the employees overall performance. According to the interview, the public banks respondents have some complaint about the environment of the bank which creates hurdle for them for their personal growth while the private bank respondents are satisfied with the corporate environment that enhances their personal grow 
Table 7. Sufficient Time of Training

\begin{tabular}{|l|l|l|l|l|l|l|}
\hline $\begin{array}{l}\text { Perceived Issues and } \\
\text { challenges faced by } \\
\text { private and public bank } \\
\text { of Punjab Pakistan }\end{array}$ & \multicolumn{2}{|l|}{ Types of institutes } & $t$ & Sig. (2 tailed) \\
\hline & Public Banks & \multicolumn{2}{l|}{ Private Banks } & & \\
\hline & Mean & $\begin{array}{l}\text { Std. } \\
\text { Deviation }\end{array}$ & Mean & $\begin{array}{l}\text { Std. } \\
\text { Deviation }\end{array}$ & & \\
\hline $\begin{array}{l}\text { Sufficient Time of } \\
\text { Training }\end{array}$ & 3.47 & .915 & 3.90 & .789 & -2.509 & .014 \\
\hline
\end{tabular}

Statistics: The mean of the public banks and private banks is 3.47 and 3.90 respectively. The standard deviation of the public and private banks is .915 and .789 respectively. The t value of the two mean is -2.509 and $p$ value is .014 . These results indicate that there is difference lies between these two means.

Public reasoning: the public banks mean is lesser than the private banks which shows that they are agree that adequate time is provided to them during the training programs. They are satisfied that they have no such time problem arises while their training duration.

Private reasoning:_the mean of the private banks is higher than the public banks which show that they are not so agreed with the time duration provided during their training. They are some complaints about the timing of the training they are of the view point they to understand something takes a time but during the training time are too little to understand whole training programs factors.

Comparison analysis:_from the above two reason it is concluded that from both sectors respondents are somehow agree with the training programs by their organizations. But they are much insisted that the time of the training provided them is not adequate to learn what the organizations want to teach. Because it takes much time to learn something which is new for them. From interview point of view many of the respondents are disagree with this statement that adequate trainings are provided to them.

Table 8. Adequate Schedules of Training

\begin{tabular}{|l|l|l|l|l|l|l|}
\hline $\begin{array}{l}\text { Perceived } \\
\text { challenges faced by private } \\
\text { and public bank of Punjab } \\
\text { Pakistan }\end{array}$ & \multicolumn{4}{|l|}{ Issues of institutes } & $t$ & Sig. (2 tailed) \\
\hline & Public Banks & Private Banks & & \\
\hline & Mean & $\begin{array}{l}\text { Std. } \\
\text { Deviation }\end{array}$ & Mean & $\begin{array}{l}\text { Std. } \\
\text { Deviation }\end{array}$ & & \\
\hline $\begin{array}{l}\text { Adequate Schedules of } \\
\text { Training }\end{array}$ & 3.60 & .990 & 3.46 & 1.014 & -2.509 & .014 \\
\hline
\end{tabular}

Statistics:_the mean of the public banks and the private banks is 3.60 and 3.46 respectively. The standard deviation of the public banks and the private banks is .990 and 1.014 respectively. The $t$ value of the two mean is -2.509 and the $p$ value is .014 which shows that there is significance difference between two mean scores. 
Public reasoning: the mean of the public banks is higher than the private banks mean which indicate that the schedules of the training are adequate when a training program is conducted. They are agreeing with the statement that schedules are predefined or preplanned before conducting the training programs. No problem arose in their job task after training has been completed.

Private reasoning:_the mean of the public banks is lower than the private banks which show that adequate schedules are provided for the training but at some extent. These respondents are of the view their banks provided training, when they think it is time to introduce something new to the employees they don't need to preplanned therefore they say that disturbance arose during in the job task.

Comparison analysis: from the above two reasons it is concluded that respondents are agree with the statement that adequate or suitable training plans are prepared before the training is started. But the interviews revealed that the private banks don't planned such programs they can start any time their programs of trainings due to which job work of employees disturbs. Interviewee of the public banks is much satisfied that they are provided relaxation from their daily task during training period.

Table 9. Effective Contents of Training

\begin{tabular}{|c|c|c|c|c|c|c|}
\hline \multirow{3}{*}{$\begin{array}{l}\text { Perceived Issues and } \\
\text { challenges faced by private } \\
\text { and public bank of Punjab } \\
\text { Pakistan }\end{array}$} & \multicolumn{4}{|c|}{ Types of institutes } & \multirow[t]{3}{*}{$t$} & \multirow{3}{*}{\begin{tabular}{|ll}
$\begin{array}{l}\text { Sig. } \\
\text { tailed })\end{array}$ & $(2$ \\
\end{tabular}} \\
\hline & \multicolumn{2}{|c|}{ Public Banks } & \multicolumn{2}{|c|}{ Private Banks } & & \\
\hline & Mean & $\begin{array}{l}\text { Std. } \\
\text { Deviation }\end{array}$ & Mean & $\begin{array}{l}\text { Std. } \\
\text { Deviation }\end{array}$ & & \\
\hline $\begin{array}{l}\text { Effective Contents of } \\
\text { Training }\end{array}$ & 3.84 & .792 & 3.92 & .752 & 699 & .487 \\
\hline
\end{tabular}

Statistics: the mean of the public banks is 3.84 and 3.92 respectively. The standard deviation of the public and private banks is .792 and .752 respectively. The $t$ value is .699 and $p$ value is .487 which shows that there is no significance difference between two mean scores at the .05 level of significance.

Public reasoning: the mean score of the public banks is 3.84 which is lower than the private banks mean score. It means that the respondents of the public banks are agree up to some extent that the contents of the training are effective and are according to the skills required for the employees. The interviews revealed that the contents and modules of the training courses are of much importance which provides the required skills.

Private reasoning: the mean of the private banks is higher than the mean score of the public banks which shows that the respondents of these banks are more agree as compared to the public banks respondents. They are of the view that because of the short time of the training contents of the trainings courses are much effective and valuable.

Comparison analysis:_from the above analysis it is realized that respondents of both sectors either public and private are satisfied that the contents and the modules of the training are preplanned according to these contents employees are provided trainings. The interviews revealed that the they are fully greed with this statement and are of the view point that if contents are not preplanned it creates hurdles for the trainers and trainees during the training is provisioned to the employees. 
Table 10. Highly Competent Trainers

\begin{tabular}{|l|l|l|l|l|l|l|}
\hline $\begin{array}{l}\text { Perceived Issues and } \\
\text { challenges } \begin{array}{l}\text { Types of institutes } \\
\text { frivate and public bank } \\
\text { of Punjab Pakistan }\end{array}\end{array}$ & \multicolumn{5}{|l|}{ Tyig. (2 tailed) } \\
\hline & Public Banks & \multicolumn{2}{|l|}{ Private Banks } & & \\
\hline & $\begin{array}{l}\text { Std. } \\
\text { Deviation }\end{array}$ & Mean & $\begin{array}{l}\text { Std. } \\
\text { Deviation }\end{array}$ & & \\
\hline $\begin{array}{l}\text { Highly Competent } \\
\text { Trainers }\end{array}$ & 3.89 & .667 & 4.14 & .639 & -.518 & .606 \\
\hline
\end{tabular}

Statistics: the mean of the public and the private banks is 3.89 and 4.14 respectively. The standard deviation of the public and the private bank is .667 and .639 respectively. The $t$ value is -.518 and $p$ value is .606 which shows that there is no significance difference between two means above at the significance level of .05.

Public reasoning: the mean of the public banks is 3.89 which is lower than the mean score of the private banks which reveals that the respondents of the public employees agree that training providers are much competent which provides training. They reveal this in the interview also that the trainers sometimes are much competent and sometimes not so competent.

Private reasoning: the mean of the private banks is 4.14 which is higher than the mean score of the public banks it intends that the respondents of the private banks are strongly agree with this statement and reveal that trainers are much competent who provide the trainings to the employees of the organization. From the interviewees it is revealed because of the short duration of the training their employers hire competent trainers for the provision of trainings to the employees in very short time period.

Comparison analysis:_from the above two reasons it is concluded that respondents of both either public or private organizations are satisfied at much level that the trainers are very competent persons who provide trainings to the employees very efficiently and effectively. Because of the lack of time or in short span of time trainers have to deliver the knowledge to the employees therefore it is considered that the trainer should be competent who takes less time while delivering training material.

Table 11. Adequate Provision of Training Material

\begin{tabular}{|l|l|l|l|l|l|l|}
\hline $\begin{array}{l}\text { Perceived Issues and } \\
\text { challenges faced by } \\
\text { private and public bank } \\
\text { of Punjab Pakistan }\end{array}$ & \multicolumn{2}{|l|}{ Types of institutes } & $t$ & Sig. (2 tailed) \\
\hline & Public Banks & \multicolumn{2}{|l|}{ Private Banks } & & \\
\hline & Mean & $\begin{array}{l}\text { Std. } \\
\text { Deviation }\end{array}$ & Mean & $\begin{array}{l}\text { Std. } \\
\text { Deviation }\end{array}$ & & \\
\hline $\begin{array}{l}\text { Adequate Provision of } \\
\text { Training Material }\end{array}$ & 3.80 & .833 & 3.78 & .996 & .109 & .913 \\
\hline
\end{tabular}


Statistics: the mean of the public banks and the private banks is 3.80 and 3.78 respectively. The standard deviation of the public banks and the private banks is .833 and .996 respectively. The $t$ value is .109 and the $p$ value is .913 at the significance level of .05 which shows that there is no significance difference between the two means.

Public reasoning: the mean of the public banks is higher than the private banks mean score it intends that the respondents of the public banks are satisfied at some extent that the hand outs and the relevant of the training is provided by the bank during the training of the employees. During the interview they revealed that due to the lack of duration of the training programs their banks provide brief material for training programs.

Private reasoning: the mean of the private banks is lower than the public banks mean score which mean the respondents of the private banks are also satisfied up to some extent. But during the interview they revealed that the material is not as sufficient as they want some time material is much but some time it is very short. They are of the view that due to short duration of the training programs it is too difficult when material is more.

Comparison analysis: from the above two reasons it is concluded that the sufficient material is provided to the trainees. But it is revealed from the interviewees of the public banks they say that the boarding facilities and other suitable facilities are not provided to them. On the other hand the private banks employees are satisfied with their institution that they provide them each and every thing relevant to the training they try to keep the trainees comfort.

\section{Recommendations}

\subsection{Sufficient Time of Training}

According to the interviewees the main problem is that the duration of training is not sufficient. They are of the view that within three to four days the employees can't learn more about the thing which they are being learning. They can't understand fully the task which they are learning. It is said that this problem can be solved by providing the sufficient time of training to the employees when they are being trained in the training centre. It is also suggested that the improvement of employees is only possible when they are being provided the sufficient time of training to the employees. Otherwise the training program will not be effective as according to the requirements of the management. When sufficient time of training is provided to the employees now they have full concentration on the training objectives. They seek with full attention and apply this training knowledge in the actual workplace tasks. The improvement takes place when employees have learnt all the trainings objectives

The implementation of the problem solution is that the training department management has to focus on the time duration of training as according to the importance of training object. Time duration can be settled before the start of the training so that employees can get full benefit of this training program.

\subsection{Effective contents of training}

According to the interviewees of different banks they are of the view that contents of trainings are not provided to the employees or trainees during the training due to which the trainees can't understand what is the goal of their training and what they have to learnt from this training program. Just management knows about have to be teach to the trainees in this training program. It is suggested that before starting the training programs the contents of training should be provided to the trainees so that they have full knowledge about what they have to learn. About what training is provided to the trainees what is the subject of training so that they can prepare themselves for learning this training? Otherwise trainees can't concentrate on the training program. They don't give much importance to the training they just try to pass the time of training in training halls. If training contents are provided to the employees before starting the training there concentration divert to the training because they know what they have to 
learn. When they know the objective of the training they learn much more from the training program and apply it in the actual work task. The work efficiency and effectiveness of the employees enhance. Implementation is only possible before the starting of training programs. The higher management of training department is responsible to give assurance of this provision of training contents to the employees so that can fully prepare themselves mental what they are going to learn.

\subsection{Preparation of staff for promotion}

Some organizations trained their old employees for meeting the globalized market requirements. During interviews the employees of the banks reveal that old employees are trained instead of hiring new employees. They are of the view that the purpose of banks is not trained to the employees for promoting them. If they are not promoting them the employees don't work with full concentration. They don't give special attention on their tasks. It is suggested that the organizations have to promote the old employees so that they can work whole heartedly. If they are not promoted even after the provision of training to the employees they don't work with full attention. It is said that to promote employees is to encourage them. You can save your organization by training their employees and promoting them due to which the quality of work improves. If you promote your old employees they work hard due to which the organization overall performance improves in the competitive corporate environment. It is suggested that implementation is only possible when you promote all the employees as according to their experience and their expertise. You should trained your employees and inform them that after this training they will be promoted.

\subsection{Improvement of research skills}

From the interviewees it is said that the training is not provided to the employees for the improvement of quality of research skills. They all disagree that no such skills are provided to the employees which enhance the research skills of the employees. But their main focus is on the training of improving the quality of services provided to the customers. Management is not serious in this research skill._It is suggested that top management has to focus on the research skills of the employees. If employees are not provided the research skills he is not able to take part in such advance activities. Organizations should give first priority to the training of the employees concerning the research skills so that employees as a team and individually can take initiatives in the product development and services as compared to their competitors. Definitely when employees are provided suitable and required research skills as according to their expertise they will be benefitted for the organization as a whole. Due to initiatives which employees shall take overall organization image in the market will enhance as well as its improvement internally. Now it is the responsibility of the top management or the training department to implement it during the training. When the organization top management member or the training department members prepare the training contents they have to included the relevant research skills contents in the training programs.

\subsection{Provision of adequate facilities}

Some of the respondents of the banks are of the saying especially of public sector banks employees that no special attention is given on the facilities which should have been given to the employees, when they come from different areas of their actual workplace to training department for attending the training programs they have to face many problems like no travelling facilities and no residence facilities etc. due to which these trainees feel bore and take tension and don't focus on training. Time of training is too short already therefore there mostly 
time is pass on searching the boarding for themselves. Management is the responsibility to facilitate their trainees so that they can focus on the concerned training instead of wasting their time in other activities. Management should focus on the provision of adequate facilities of intercity conveyance and boarding to outside city trainees, So that their focus shall remain on the actual task of training. If such facilities are provided to the trainees they shall be very happy and encouraged on this provision of facilities by the organization to them. There focus will remain on the training instead of anywhere else. When such facilities are provided to the trainees next time they don't take tension while attending the training programs of their organization. Implementation is made by the training department. Because such initiatives are undertaken by this department therefore before the start of training all such facilities should be arranged before the arrival of the trainees in the training place. If such facilities are not arranged by the training department the trainees discouraged therefore which is the loss for the organization.

\subsection{Provision of reward and incentives}

From the interview respondents, it is said that no rewards and incentives are provided to the employees or trainees either in form of money or in form of certificates etc. if these types of incentives are not provided to the employees then employees are discouraged and second time they hesitate and deny to attend the training programs. If sufficient rewards or certificates are provided to the trainees or employees they are encouraged. They shall work with honesty, hardworking and try to enhance the organization growth overall. They feel proud when they receive such certificates. They think that if they shall leave the organization due to some reasons they shall have been such certificates due to which they shall not be worry about searching another job. Main benefit to the organization is that they work to much hard. They try to improve the quality of services up to that extent which they could do. They try to improve the organization overall. They become the root cause of growth of the organization in future time. Top management or the training department should focus on such rewards system. When they start training they should keep in mind the rewards system to the trainees. Rewards or certificates should have to be provided on the completion of the training.

\section{Conclusion}

Every efficient corporate environment is the result of efficient and talented management of the organization. No one organization is complete in its competitive corporate environment which has no efficient human workforce. To improve that organizations are going to success is the result of talented and skilled human resource management. To run the business corporation on the track of competition its too important to keep the hard work and well educated workforce. The survival of any organization is only possible when its workforce has the ability to face all the forefront problems with their competitors. Those organizations which have no competent and skilled employees can not survive in this globalized corporate environment of competition. To achieve the competitive advantage over the competitors existing either in the domestic as foreign market the skillful workforce is the solution. After finding and in our research paper professional development is too necessary for the improvement of employees working in the organization. To improve the organization efficiency it is necessary first to improve the efficiency of the employees. When you improve the skills, knowledge and experience of the employees now you are able to improve the product of the organization. When organization product quality is enhanced it is the basically the enhancement of the organization's quality which become the root cause of an organization's reputation in the competitive market. Many organizations are providing training to their employees by different ways. Different types of trainings are provided to the employees before the start of their actual positive work during the 
job. Because this research paper is the study of Punjab banks either public or private. Each and every bank has its own special training departments where they trained their employees to meet the globalized rapid competitive environment. On the basis of the findings, the following conclusions were drawn. The main findings presented in this research support the hypothesis that The professional development of the banks employees has a positive and significant influence on the work environment. It refers primarily to the management commitment that describes the right work tasks and goals of the banks employees by training them with the strong commitment of the banks executives. Our main finding suggests that management commitment is critical in professional development to enhance capabilities of the employees. It is argued that professional development cannot itself take effect unless supported by the immediate managers and possibly the higher management Skills and experience. This influence of training of employees comes separately through different factors that may influence training cumulatively through a unified effect of all the components together. Knowledge gained during training need to be reinforced on the job and that is achieved when staff is trained with support from the management. Ideally, supportive management positively contributes towards application and transfer of training in the environment of organization tasks. It is the management that creates the required positive environment and provides the necessary input both before and after the training programs. Majority of the respondents were of the view that their supervisors facilitate training endeavors. They also believed that there was a lack of interest on the part of management in discussing the training program before and after the training and also in the application of training as soon as the training was over. It reveals that training and skills development as a tool of HR intervention in the banking sector in particular is recognized at the introduction level. In view of the challenges ahead and the importance of Human Resource in developing and emerging economies, such HRD measures need further strengthened. The training environment in the banking sector at present could be categorized as either neutral or positive. One way to create a positive and conducive training environment is to involve the management itself in the development of the training programs. This may increase the motivation level of the trainees and the desire to apply and transfer learning on the job. Similarly, technical support in the modern era is necessary for the training of the employees in the corporate world of the banking sector. Increased automation and software facilities imply greater importance for the training of the employees. Interestingly, it is observed that besides increased automation, the employees still hold the view that the required manpower was not provided to them during the training. Analysis of responses on workload shows that there was no increase in the workload after training namely in the period immediately after training, the period of transfer. Work remained normal and the working hours were not sufficient for transferring newly learnt skills. Majority of respondents agree that additional financial resources and budgetary allocations were well within the reach of their organization. However, they believed that their organization did not support demand for additional funds. This issue may be due to the fact that training is a recent phenomenon in the banking sector and expenditure incurred on training is considered a cost and not an investment, particularly by small banks. The research also leads us to the conclusion that generally there are no impediments to implementation at will whatever the bank officers learn during training, unless such initiatives conflict with the existing corporate policies. Thus, most bank officers are free and have the opportunity to perform and take the initiative of training. The nature of job in the banking sector is more or less based on team work. The procedures/policies/manuals are well defined. Thus, the standing instructions from the head office could limit the initiatives of individual officers to apply learning acquired during training programs. Thus it can be safely concluded that good organizational training environment has an enduring and positive influence on bank officers' transfer of training in their banks. This study highlights various aspects necessary for the training of the employees to improve their performance. It is observed 
that there is direct relationship between training and employees work environment. According to the employees the rewards are not appropriate to their needs. The rewards received from the organization were inadequate to their needs. Promotion process was observed to be very slow and rhe recognition was informal that it was felt like unnecessary with no extrinsic forms. It was suggested that informal recognition should be changed to formal way.

\section{References}

1. Akhtar, S. (2008, March 13). Corporate Governance for Banks. Retrieved June 18, 2008, from www.sbp.org.pk/about/speech/governors/dr.shamshad/2008/IBP-13-Mar08.pdf.

2. Baldwin, T., \& Ford, J. (1988). Transfer of training: A review and direction for future research. Personal Psychology, 41, 63-105.

3. Blumenfeld, W., \& Holland, M. (1971). A Model for the Empirical Evaluation ofTraining Effectiveness. Personnel Journal, 50(8), 637-640.

4. Blumenfeld, W., \& Holland, M. (1971). A Model for the Empirical Evaluation ofTraining Effectiveness. Personnel Journal, 50(8), 637-640.

5. Bremley, P., \& Kitson, B. (1994). Evaluating Training Against Business Criteria Journal of European Industrial Training, 18(1), 10-14.

6. Daft, R., \& Steers, R. (1986). Organizations: A Micro/Macro Approach. Glenview, Illinois: Scott, Foresman and Company.

7. Davis K, Newstrom J (1999). Comportamiento Humano en el Trabajo: Comportamiento Organizaciona (10th Edn). Mexico: McGraw-Hill

8. Eason KD (1989). Information Technology and Organizational Change. London: Taylor \& Francis

9. Emery FE (1992). The Management of Self-Managing Groups'. In Emery, M. (ed.) Participative Design for Participative Democracy. Canberra: Australian National University Centre for Continuing Education. pp. 165 - 61

10. Greenhaus, J., Callanan, G., \& Godshalk, V. (2000). Career Management. Fort Worth: The Dryden Press, Harcourt College Publishers.

11. Guest DE (2004). "Flexible employment contracts, the psychological contract and employee outcomes: an analysis and review of the evidence". Int. J. Manage. Rev. 5/6 (1): 1 - 19 .

12. Newstrom, J. (1986). Leveraging management development through the management of transfer. Journal of Management Development, 5(5), 33-45.

13. Nguyen A, Taylor J, Bradley S (2003). Relative Pay and Job Satisfaction: Some New Evidence, MPRA Paper No 1382

14. Noe, R. (2002). Employee Training and Development. New York: McGraw-Hill.

15. Noe, R., Hollenbeck, J., Wright, P., \& Gerhart, B. (2006). Human Resource Management: Gaining a Competitive Advantage. Boston, MA: McGraw-Hill Irwin.

16. Petrescu AI, Simmons R (2008). Human resource management practices and workers' job satisfaction, Int. J. Manpower. 29(7): $651-667$ 
17. Rouiller, J., \& Goldstein, I. (1993). The relationship between organizational transfer climate and positive transfer of training. Human Resource Development Quarterly, 4(4), 377-390.

18. Sels L, De Winne S, Maes J, Delmotte J, Faems D, Forrier A (2006). Unravelling the HRM-performance link: Value-creating and cost-increasing effects of small business HRM, J. Manage. Stu. 43(2): 319 - 342.

19. Silla I, Gracia F, Peiró JM (2005). Job insecurity and health-related outcomes among different types of temporary workers, Eco, Ind. Democracy, 26: 89-117.

20. State Bank Of Pakistan. (2005). Annual Report, 2005. Karachi: State Bank of Pakistan.

21. State Bank Of Pakistan. (2007). Annual Performance Review, 2006-7, Vol. 2. Karachi: State Bank of Pakistan.

22. State Bank Of Pakistan. (2007). Banking Sector Review, 2007. Karachi: State Bank of Pakistan.

23. Swinney, J. (1989). Who's gonna turn the crank OR Implementing training orperformance improvement projects. Performance \& Instruction, 28(1), 33-37

24. Tanke ML (1990). Human Resources Management for the Hospitality Industry, Delmar Publishers, Albany, NY. 